\title{
Future Coastal Population and Ecosystem Exposure to Sea Level Rise Along the European Coastline
}

\author{
Shrinidhi Ambinakudige
}

\section{ABSTRACT}

The average global sea level has been predicted to rise anywhere between 0.53 $2.5 \mathrm{~m}$ by 2100 with some local and regional variations in various climate change scenarios. Relative sea level change along most of the European coastline is similar to the global average. The objective of this paper is to estimate the extent of impact regarding three sea level rise (SLR) scenarios on European coastal regions. First, three inundation models estimate the area affected by the base sea level, $1 \mathrm{~m}$ SLR, and $2 \mathrm{~m}$ SLR. Then, based on the population and land cover classes in the coastal regions, land cover types and the estimated future population affected by the SLR scenarios are analyzed. This study used an inundation model (EU-DEM v1.1 digital elevation model). Land cover data from CLC2018 and monthly averaged sea level anomalies (SLA) files from 2013 to 2015 were used in the model. In the SLR0 scenario, about 8.7 million people are estimated to be affected at 2100 . An estimated 11.6 million people will be affected in the SLR1 scenario; and an estimated 14.8 million people will be affected by the SLR2 scenarios. Arable lands and pastures are the two top land cover classes that will be affected by SLR. However, land under urban fabric and transportation are also two important land cover types affected by SLR which can induce major economic costs to coastal countries. A significant area of underwater bodies and wetlands will come in contact with sea water due to the extreme events caused by SLR.

Keywords: Coastal, Europe, Mean Sea Level, Sea Level Rise.
Published Online: October 25, 2020

ISSN: 2684-446X

DOI :10.24018/ejgeo.2020.1.5.80

Shrinidhi Ambinakudige*

Mississippi State University, USA.

(e-mail: ssa60@msstate.edu)

*Corresponding Author

\section{INTRODUCTION}

Global sea level rise (SLR) is linked to climate change. Although sea level fluctuation is a slow ongoing natural process and fluctuates on a geological timescale, in recent decades sea levels have fluctuated significantly in many parts of the world due to human-induced causes of climate change [1]. In the last 25 years, SLR was 3 times higher $(\sim 3 \mathrm{~mm} / \mathrm{yr})$ than during the previous century $(\sim 1.2 \mathrm{~mm} / \mathrm{yr})$ [2]-[4]. Studies suggest that a $1-5 \mathrm{~m}$ rise in sea level by 2100 is expected due to thermal expansion of ocean water, melting of ocean glaciers, ice sheet disintegration [5]-[11]. SLR brings in more storm surge, tides, wave events, flooding, drainage problems, saltwater intrusion into coastal ecosystems and aquifers, and increased beach erosion [12]. SLR, along with regional climate variations, can exacerbate impacts and alter coastal landscapes, their ecosystem services, and coastal populations [4], [11].

Throughout the world, coastal areas are booming with economic activities and attracting people [13], and this trend is expected to continue in the coming decades [14]. Coastal zones, already densely populated, have very high population growth rates, which means that in the future, a greater number of people will be living in SLR hazard areas who will be vulnerable to climate change [15]. SLR presents both shortterm and long-term risks that will require heavy investment in infrastructure and probably result in displacement [12]. SLR brings inundation of homes and properties in low-lying coastal settlements and increases in the inland penetration of coastal hazards such as storm surges, tsunamis, and tides [12]. In addition, rising sea temperatures elevate the sustained wind speed of tropical storms, cyclones, and hurricanes [16].

SLR is one of the most likely causes of social disruption during future climate change situations [17]. In Europe, like in many other parts of globe, densely populated coastal areas will face significant direct or indirect socioeconomic impacts of SLR. Such impacts will include economic, ecological, and cultural losses as well as subsistence shocks through loss of land, infrastructure, and coastal habitats. Further, increased flood risk will bring changes in water quality, salinity, and biological activity [11]. For example, in 1953, Europe experienced one of the worst coastal flooding events in Europe when a severe storm surge and a high spring tide caused devastation to live and properties. More than 2,000 people 
died in the Netherlands, Belgium, and the UK, and the storm surge damaged or destroyed more than 40,000 buildings [18]. While the short-term impacts of sea level rise are also significant, in the long term it can cause considerable damage to coastal communities.

Studies have attempted to analyze the impacts of climate change with population growth trends [17], [19]-[21]. A study [17] used a model to align small-area population projections spatially and temporally from coastal states in the continental United States to 2100. This helps to assess how many people are potentially at risk of impact from SLR and what areas are likely to experience the greatest population exposure to SLR.

The objective of this paper, therefore, is to estimate the extent of impact of three SLR scenarios on European coastal regions. First, three inundation models will estimate the area affected by the base sea level, $1 \mathrm{~m}$ SLR and $2 \mathrm{~m}$ SLR. The control period for SLR measurement is 2013-2015 in this study. Although, Representative Concentration Pathway (RCP) models estimate the SLR during the 21st century (i.e. in 2100, compared with 1986-2005) to be likely in the range of 0.29-0.59 m for RCP2.6, 0.39-0.72 $\mathrm{m}$ for RCP4.5, and 0.61$1.10 \mathrm{~m}$ for RCP8.5, Several recent model-based studies suggest upper limits of 2100 global mean sea level from $1.5 \mathrm{~m}$ to $2.5 \mathrm{~m}$ [22], [23]. Therefore, in this study, selecting 20132015 as base year and choosing $1 \mathrm{~m}$ and $2 \mathrm{~m}$ SLR scenarios will not be an overestimate. Although, coastal regions in Europe have experienced an increase in absolute sea level with significant regional variation this study uses uniform SLR scenarios for all the regions. The second objective is to estimate population and land cover classes affected by the SLR scenarios based on the current population and land cover classes in the coastal regions of Europe.

\section{SLR MODELS AND STUDIES}

According to the Intergovernmental Panel on Climate Change (IPCC) report on sea level change, by the end of the 21 st century, it is very likely that for about $95 \%$ of the world's oceans, regional sea level rise will be positive [24]. Many studies have estimated the extent of impact of SLR on coastal communities. Sea level rise and coastal hazards together can result in coastal flooding [25]-[29] and increased storm surge events [15], [30]-[33]. Many studies have estimated the economic impacts of sea level rise on developed properties along the shoreline [34], agriculture, forestry, ecosystems, communities, and water resources [25], [35], [36]. Studies [37], [38] have documented the influence of sea level rise on increasing population exposure to future hurricane stormsurge hazard zones. Studies have [17], [21] analyzed sea-level rise in the United States and its consequences on population and migration. The continuing development of coastal areas calls for a comprehensive vulnerability assessment of coastal communities [30].

Models have predicted the impacts of sea levels on various aspects of coastal infrastructure. The DIVA_WCM model [39], which predicted that with $50 \mathrm{~cm}$ of SLR by 2100 , there will be a loss of $46-59 \%$ of global coastal wetland stocks. It also predicted a global coastal wetland loss of $78 \%$ under high
SLR (110 cm by 2100). A study [40] estimated flood risk and wetland losses due to SLR using the global SLR scenarios derived from two general circulation models (GCMs) and found that flood frequency will increase due to SLR, which requires some response such as increased protection and migration. Most vulnerable to flooding are the southern Mediterranean, Africa, and, most particularly, South and Southeast Asia where there is a concentration of low-lying populated deltas. They also found that by the 2080s, SLR could cause the loss of up to $22 \%$ of the world's coastal wetlands.

A global vulnerability assessment (GVA) was done to estimate the socio-economic and ecological implications of accelerated SLR [41], [42]. It used the IPCC Common Methodology [43]. This study analyzed coastal flooding, wetland loss, and rice production at change. A study [42] has estimated that a $1 \mathrm{~m}$ rise in sea level by 2100 would affect 60 million people per year.

Inundation models have been used to predict areas that will be flooded due to SLR based on quantitative relationships between climate and topography of the coastal areas. These models identify those areas that lie below a given elevation contour. Inundation models incorporate various SLR scenarios, providing an approximation of coastal vulnerability to sea level. Potentially inundated areas can be calculated (e.g., in GIS). Some of the impacts of SLR are inundation and displacement of wetlands and low-lying lands, increased coastal erosion, increased coastal flooding, and saltwater intrusion into estuaries, deltas, and aquifers. Coastal flooding is the result of infrequent extreme sea levels produced by storms or significant run-off from the land [44, 45]. Effects of SLR on flood risk are coastal erosion and destruction of coastal ecosystems reducing the natural protection against a surge $[44,45]$.

\section{MATERIALS AND METHODS}

In this study, an inundation model is used to estimate the area affected by different SLR scenarios. Mean sea level (MSL) is an average over all the oceans of sea surface height with respect to a datum. Variations of MSL along time is an important indicator of climate change. For over 20 years now, the global MSL has been routinely measured with highprecision satellite altimetry, and such observations provide clear evidence of a global MSL rise of about $3.16+/-0.5 \mathrm{~mm}$ [1]. Satellite altimetry, autonomous floats (Argo floats since 2003), and gravimetry data (Grace satellite) enable measurement of MSL variations. The satellite altimetry missions have been measuring the global MSL on a continual basis since January 1993. Many satellites have been used such as Topex/Poseidon-Jason-1, then Jason-1-Jason-2, Envisat, ERS-1, and ERS-2. The new altimetry missions such as Sentinel-3 and Jason-3 are providing further improvement to measurement of MSL [46].

The European Space Agency (ESA) has initiated a program called the Global Monitoring of Essential Climate Variables (or ESA Climate Change Initiative) to provide adequate, comprehensive, timely, and long-term satellite-based products 
to study climate change. This study used monthly averaged sea level anomalies (SLA) files from 2013 to 2015 . These files are SLA grids computed after merging all the altimeter mission measurements into monthly grids. A conditional algorithm was used to calculate the maximum height from the 36 2013-2015 monthly grids for each pixel in the European coastal regions. The resulting grid is the base MSL in this study. The MSL is then interpolated to create an MSL grid for the entire study region.

To calculate the initial inundation, the base MSL grid and the EU-DEM v1.1 were used; the EU-DEM v1.1 is a digital surface model (DSM) of EEA39. This is a fusion of SRTM and ASTER GDEM data. This data is relatively unbiased ($0.56 \mathrm{~m}$ ) with an overall vertical accuracy of $2.9 \mathrm{~m}$ RMSE [47]. The EU-DEM v1.1 has more accuracy with bias adjustment with ICESat, corrections to artefacts. The EU-DEM has $25 \mathrm{~m}$ resolution and uses ETRS89-LAEA (EPSG Code 3035), Ellipsoid GRS80, and vertical datum EVRS2000 with geoid EGG08 [47]. Data were downloaded from the Copernicus website. A conditional function was created to construct an initial (SLR0 scenario) inundation grid using the formula Initial inundation $=$ Con(EuroDEM $<=$ MSL, MSLEuroDEM). Three SLR scenarios were considered: the base level (SLR0), an optimistic projection of $1 \mathrm{~m} \mathrm{SLR} \mathrm{(SLR1)} \mathrm{and}$ a pessimistic projection of $2 \mathrm{~m}$ SLR (SLR2). Similarly, for a one-meter increase in sea level, a one-meter height was added to the base MSL grid, and a new conditional function was run in ArcGIS. The same method was used to estimate the inundation due to $2 \mathrm{~m}$ increase in MSL.

Land cover data was obtained from the Corine Land Cover European seamless vector database (RELEASE v20), also known as CLC2018, which is one of the datasets produced within the frame of the Corine Land Cover programme coordinated by the European Environment Agency (EEA). This land cover data comes with 44 land cover classes in the hierarchical 3-level Corine nomenclature (https://land.copernicus.eu/pan-european). The CLC2018 data layer was overlaid on different SLR scenario grids to estimate the areas of different land cover classes that will be affected by SLR.

For demographic data, European Local Administrative Unit (LAU) population data, complied and provided by Eurostat (https://ec.europa.eu/eurostat/web/nuts/local-administrativeunits) for the period 1961-2011, was used. The data collection covers EU member states, certain candidate countries, and EFTA countries. For this study, a population growth rate was calculated between 1991 and 2011. This rate was used to estimate the 2100 population for each LAU. To estimate the impact of SLR, LAU boundaries with estimated demographic and land cover data were overlaid on different SLR scenarios. A spatial intersection of SLR scenario data and the LAU provided the proportion of area of each LAU that will inundated in each SLR scenario. Portion of the LAU area that will be inundated was then assigned the population value proportion to its area. Similarly, spatial intersection of LAU and land cover data provided the extent of each land cover class affected by SLR scenarios.

\section{RESULtS}

Results indicate that in Europe, more than 70 million people are living in coastal LAUs, which accounts for nearly $11 \%$ of the total population. To analyze how these people and coastal ecosystems will be affected by various SLR scenarios, three SLR scenarios were considered: base sea level (SLR0), an optimistic projection of $1 \mathrm{~m}$ SLR (SLR1) and a pessimistic projection of $2 \mathrm{~m}$ SLR (SLR2). Results indicate that about 108 provincial capitals in Europe will have some parts of their cites affected by the inundation caused by the SLR1 scenario. About 114 provincial capitals in Europe will have some parts of their cites affected by the inundation caused by the SLR2 scenario.

Results indicate that the highest number of people affected by the SLR is in the Netherlands (Table 1). In the Netherlands the SLR0 scenario will affect an area that will be home to about 3.86 million people in 2100 . The impacts will be from storm surges and other inundations. The SLR1 scenario will affect an estimated 4.88 million people, and the SLR2 scenario will affect an estimated 5.77 million people. One-third of the Netherlands is located at a below-average sea level; this lowlying country is highly vulnerable to the consequences of storm surges. To protect its coastal area, the Netherlands has been working on better water management practices, including the introduction of dike rings in the majority of the threatened areas and proper maintenance of drainage systems. Technology has played an important role in water management [48]. Because of the well-developed water management practices in the Netherlands, actual impact may be much smaller there than in other European countries.

TABLE I: ESTIMATED NUMBER OF PEOPLE (IN THOUSANDS) THAT WILL BE AFFECTED BY THE THREE SLR SCENARIOS BY 2100

\begin{tabular}{|l|r|r|r|}
\hline \multicolumn{1}{|c|}{ Country } & \multicolumn{1}{c|}{ SLR0 } & \multicolumn{1}{c|}{ SLR1 } & \multicolumn{1}{c|}{ SLR2 } \\
\hline Netherlands & 3,861 & 4,887 & 5,779 \\
\hline Germany & 3,080 & 3,366 & 3,748 \\
\hline Denmark & 256 & 843 & 1,162 \\
\hline Italy & 578 & 816 & 1,137 \\
\hline Poland & 361 & 414 & 494 \\
\hline Spain & 140 & 279 & 481 \\
\hline Belgium & 132 & 263 & 422 \\
\hline UK & 93 & 230 & 491 \\
\hline France & 48 & 154 & 369 \\
\hline Albania & 93 & 135 & 172 \\
\hline Greece & 32 & 67 & 119 \\
\hline Sweden & 17 & 38 & 77 \\
\hline Portugal & 9 & 33 & 86 \\
\hline Latvia & 22 & 30 & 41 \\
\hline Montenegro & 2 & 23 & 24 \\
\hline Finland & 0 & 20 & 82 \\
\hline Romania & 12 & 19 & 24 \\
\hline Lithuania & 14 & 18 & 22 \\
\hline Croatia & 3 & 6 & 9 \\
\hline Ireland & 2 & 5 & 19 \\
\hline Norway & 0 & 4 & 11 \\
\hline Northern Ireland & 1 & 3 & 7 \\
\hline Scotland & 0 & 2 & 11 \\
\hline Iceland & 0 & 1 & 2 \\
\hline Estonia & 0 & 0 & 1 \\
\hline
\end{tabular}

Coastal flooding from extreme water levels (WL) is considered a major risk for the coastal low-lying areas of 
Germany. This is another country where a large number of people will be affected by SLR. With the SLR0 scenario, an estimated 3 million people will be affected by 2100 . This could increase to 3.36 million people in the SLR1 scenario and 3.74 million people in the SLR2 scenario (Table 1). Like the Netherlands, Germany has also invested in creating defense mechanisms such as dikes as well as dunes with grass cover and asphalt [49]. These efforts will greatly help to mitigate SLR impacts.

Denmark is another country that will be affected. An estimated 0.26 million people will be affected by the SLR0 scenario, 0.83 million people will be affected by the SLR1 scenario, and 1.16 million people will be affected by the SLR2 scenario (Table I). The southwestern part of the country seems to be more vulnerable to SLR. Cities like Denmark's Copenhagen will experience the externalities of SLR. More than $1,100 \mathrm{~km}$ of Denmark's coastline is protected by dikes [50]. In Italy, a significant number of people are already affected by extreme levels of flooding and waterlogging due to SLR. The population that will be affected by the SLR0 scenario is estimated to be 0.58 million, which could increase to 0.82 million in the SLR1 scenario and 1.13 million in the SLR02 scenario (Table 1). The Italian coast of the northern Adriatic Sea is one of the areas that are most vulnerable to SLR. This area is the delta of the Po river and many other rivers such as the Isonzo, Tagliamento, Piave, and Brenta rivers. Many parts of this region have some coastal defense structures. Flooding events are common in this region because of the Po river overflow or from sea surge [51], [52]. With the increased population and increased storm surges and flooding, this area will face significant changes, both physically and demographically.

The Polish coastal zone is another area in Europe that could be affected severely by SLR. The increase in the frequency of storm surges could elevate the risk to the population and economy in Poland, but cost-effective flood protection measures could mitigate the risk [53]. The SLR0 scenario will affect an estimated 0.36 million people; the SLR2 scenario could affect 0.41 million people; and the SLR 2 scenario could affect an estimated 0.49 million people in Poland (Table I).

Spain's Mediterranean coastline is another area that could be affected severely due to SLR. Spain is a European coastal country that has coastal edges over both the Atlantic Ocean and the Mediterranean Sea. The coastal areas of Spain are experiencing extreme urban pressure. There could be an estimated 0.28 million people affected in the SLR1 scenario, and an estimated 0.48 million people could suffer the consequences of storm surges and flooding in the SLR2 scenario (Table I). Generally, Spain has a high overall vulnerability to flooding and erosion, but SLR could intensify flooding intensity and disappear many beaches.

Similarly, SLR will affect large numbers of people Belgium, Albania, the UK, and France (Table I). Although the number of people affected by SLR scenarios are small in these countries, it is important to note that the overall economic and cultural impact of these different SLR scenarios are not any less compared to other European countries.

SLR can affect coastal ecosystems and infrastructure as well as agricultural and other lands. Among the 15 land use and land cover classes analyzed in this study, arable land (Fig. $1 ; 38 \%$ in SLR1 and $37 \%$ in SLR2) and pastures (28\% in SLR1 and 25\% in SLR2) are the two major land cover types that will be inundated due to storm surges and flooding from SLR. While inland waters and inland wetlands are land cover classes most affected by SLR, agricultural areas are also in danger with about 4\% inundated in the SLR1 scenario and 5\% in the SLR2 scenario. About 3\% of the land inundated will be urban fabrics.

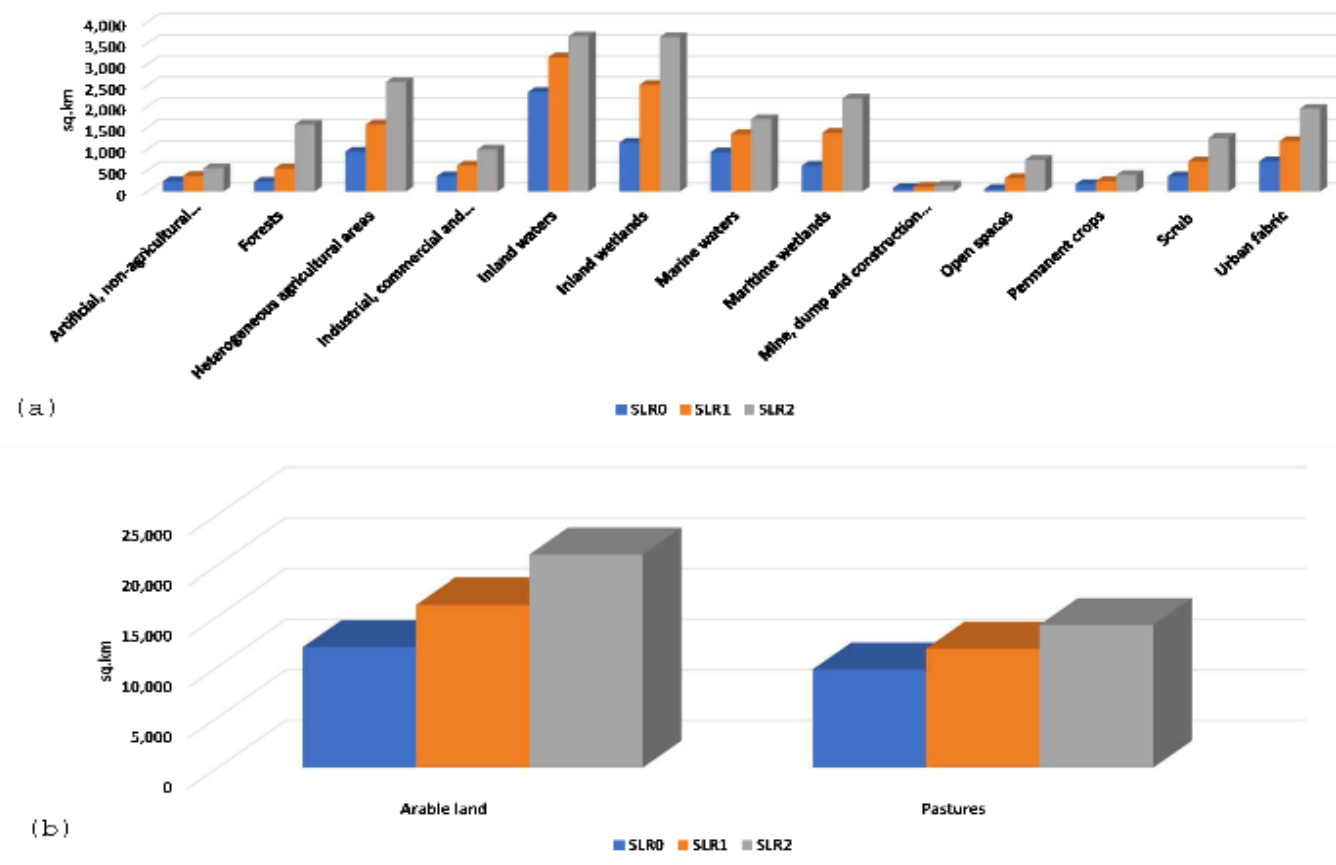

Fig. 1. (a \& b). Areas of land use and land cover classes estimated to be affected by the three SLR scenarios. 
European Journal of Environment and Earth Sciences www.ej-geo.org

\begin{tabular}{|c|c|c|c|c|c|c|c|c|c|c|c|c|c|c|c|c|}
\hline Countries & Arable & $\begin{array}{c}\text { Non } \\
\text { Agricultural } \\
\text { Vegetated }\end{array}$ & Forest & $\begin{array}{l}\text { Agricultu } \\
\text { ral areas }\end{array}$ & $\begin{array}{c}\text { Industri } \\
\text { al }\end{array}$ & $\begin{array}{l}\text { Inland } \\
\text { waters }\end{array}$ & $\begin{array}{c}\text { Inland } \\
\text { wetlands }\end{array}$ & $\begin{array}{l}\text { Marine } \\
\text { waters }\end{array}$ & $\begin{array}{l}\text { Maritime } \\
\text { wetlands }\end{array}$ & $\begin{array}{c}\text { Mine } \\
\text { and } \\
\text { dump }\end{array}$ & $\begin{array}{c}\text { Open } \\
\text { spaces }\end{array}$ & Pastures & $\begin{array}{l}\text { Permanen } \\
\mathrm{t} \text { crops }\end{array}$ & Scrub & Urban & Total \\
\hline Albania & 177.4 & 0.4 & 5.5 & 31.1 & 2.7 & 4.8 & 12.7 & 51.7 & 51.0 & 0.0 & 8.9 & 8.1 & 0.1 & 25.6 & 16.7 & 396.9 \\
\hline Belgium & 92.7 & 0.6 & 0.6 & 57.4 & 4.9 & 21.1 & 0.9 & 26.6 & 1.2 & 2.9 & 0.0 & 45.3 & 0.1 & 1.6 & 1.0 & 256.9 \\
\hline $\begin{array}{l}\text { Bosnia and } \\
\text { Herzegovina }\end{array}$ & 0.2 & 0.0 & 0.0 & 0.1 & 0.0 & 0.9 & 1.2 & 0.0 & 0.0 & 0.0 & 0.0 & 0.0 & 0.0 & 0.0 & 0.0 & 2.3 \\
\hline Bulgaria & 10.5 & 0.6 & 0.0 & 1.5 & 0.3 & 36.0 & 2.6 & 0.7 & 3.3 & 0.2 & 0.1 & 0.4 & 0.1 & 0.1 & 0.0 & 56.4 \\
\hline Croatia & 16.2 & 0.1 & 0.4 & 10.0 & 0.4 & 32.5 & 16.8 & 0.0 & 1.9 & 0.3 & 0.2 & 0.3 & 16.0 & 0.3 & 0.4 & 95.8 \\
\hline Cyprus & 0.1 & 0.1 & 0.0 & 0.0 & 0.6 & 0.0 & 0.1 & 0.0 & 16.5 & 0.0 & 2.4 & 0.0 & 0.0 & 0.9 & 0.0 & 20.9 \\
\hline Denmark & 550.9 & 14.7 & 4.5 & 73.5 & 6.8 & 97.6 & 39.5 & 19.5 & 63.5 & 3.2 & 2.0 & 40.7 & 0.2 & 32.9 & 4.2 & 953.7 \\
\hline Germany & 1896.7 & 13.0 & 26.5 & 14.8 & 29.9 & 198.9 & 213.9 & 65.7 & 70.4 & 4.8 & 3.1 & 4091.5 & 73.1 & 117.9 & 54.5 & 6874.6 \\
\hline Spain & 167.1 & 0.5 & 0.1 & 2.0 & 2.0 & 4.1 & 6.3 & 19.2 & 56.3 & 0.8 & 9.4 & 5.3 & 1.7 & 4.5 & 2.7 & 282.0 \\
\hline Estonia & 0.0 & 0.0 & 0.0 & 0.0 & 0.0 & 0.0 & 0.1 & 0.0 & 0.0 & 0.0 & 0.0 & 0.0 & 0.0 & 0.2 & 0.0 & 0.4 \\
\hline Finland & 0.0 & 0.0 & 0.0 & 0.0 & 0.0 & 0.0 & 0.0 & 0.0 & 0.0 & 0.0 & 0.0 & 0.0 & 0.0 & 0.0 & 0.0 & 0.0 \\
\hline France & 103.4 & 0.7 & 0.5 & 9.0 & 3.2 & 44.3 & 88.2 & 24.4 & 34.8 & 1.6 & 1.6 & 58.6 & 4.1 & 3.3 & 1.6 & 379.3 \\
\hline Greece & 172.8 & 0.8 & 0.2 & 8.8 & 2.4 & 16.5 & 20.9 & 27.4 & 68.7 & 0.6 & 8.4 & 0.9 & 2.0 & 4.6 & 0.9 & 335.8 \\
\hline Iceland & 0.0 & 0.0 & 0.0 & 0.0 & 0.0 & 0.5 & 0.1 & 0.1 & 0.4 & 0.0 & 0.2 & 0.1 & 0.0 & 0.6 & 0.0 & 2.0 \\
\hline Ireland & 10.9 & 0.2 & 1.4 & 2.0 & 0.3 & 18.3 & 1.4 & 1.0 & 0.9 & 0.7 & 0.1 & 10.8 & 0.0 & 0.0 & 0.1 & 48.1 \\
\hline Italia & 3157.3 & 12.0 & 8.9 & 176.6 & 39.7 & 99.7 & 26.9 & 123.8 & 122.1 & 4.1 & 1.2 & 2.5 & 42.0 & 6.5 & 40.0 & 3863.4 \\
\hline Latvia & 39.6 & 2.3 & 0.5 & 6.0 & 2.2 & 162.5 & 45.1 & 0.0 & 0.0 & 1.5 & 0.1 & 47.9 & 0.0 & 2.6 & 1.9 & 312.2 \\
\hline Lithuania & 49.9 & 0.2 & 7.9 & 27.8 & 1.5 & 36.9 & 43.0 & 0.6 & 0.0 & 0.1 & 0.1 & 142.3 & 0.0 & 11.8 & 2.5 & 324.7 \\
\hline Montenegro & 0.0 & 0.2 & 0.2 & 0.6 & 0.1 & 3.5 & 2.0 & 0.4 & 13.8 & 0.0 & 0.4 & 0.5 & 0.0 & 2.4 & 0.2 & 24.1 \\
\hline Netherlands & 4049.8 & 181.5 & 132.3 & 455.6 & 239.5 & 555.0 & 272.7 & 0.5 & 26.6 & 51.0 & 2.9 & 4613.9 & 33.3 & 108.5 & 553.0 & $\begin{array}{c}11276 . \\
2\end{array}$ \\
\hline Norway & 0.3 & 0.0 & 11.7 & 1.9 & 0.0 & 11.2 & 0.0 & 0.3 & 0.0 & 0.1 & 1.1 & 0.0 & 0.0 & 1.4 & 0.1 & 28.4 \\
\hline Poland & 903.0 & 8.6 & 23.6 & 57.9 & 12.2 & 329.6 & 82.7 & 1.2 & 0.0 & 7.3 & 1.0 & 522.0 & 1.4 & 14.6 & 31.5 & 1996.6 \\
\hline Portugal & 8.4 & 0.0 & 0.3 & 0.6 & 0.7 & 6.6 & 0.0 & 15.0 & 9.1 & 0.0 & 0.2 & 2.1 & 0.0 & 1.0 & 0.1 & 44.1 \\
\hline Romania & 111.7 & 0.4 & 2.5 & 0.3 & 0.3 & 360.6 & 217.5 & 518.2 & 35.1 & 0.9 & 3.9 & 2.0 & 0.0 & 10.8 & 0.7 & 1264.9 \\
\hline Slovenia & 0.2 & 0.1 & 0.0 & 0.2 & 0.6 & 0.7 & 0.0 & 0.0 & 0.4 & 0.3 & 0.0 & 0.0 & 0.0 & 0.0 & 0.0 & 2.7 \\
\hline Sweden & 24.4 & 2.7 & 1.4 & 2.2 & 1.4 & 21.7 & 8.0 & 1.9 & 0.8 & 1.9 & 0.6 & 24.2 & 0.0 & 1.0 & 0.6 & 92.6 \\
\hline Turkey & 8.0 & 0.7 & 0.4 & 3.4 & 0.8 & 263.1 & 21.3 & 25.4 & 25.6 & 1.6 & 9.8 & 1.3 & 0.6 & 2.9 & 1.0 & 366.1 \\
\hline Ukraine & 0.0 & 0.0 & 0.0 & 0.0 & 0.0 & 0.0 & 0.0 & 0.0 & 0.0 & 0.0 & 0.0 & 0.0 & 0.0 & 0.0 & 0.0 & 0.0 \\
\hline United Kingdom & 399.2 & 1.5 & 0.4 & 2.4 & 6.0 & 14.7 & 29.6 & 6.9 & 9.3 & 2.8 & 0.1 & 118.4 & 0.0 & 1.2 & 1.7 & 594.2 \\
\hline
\end{tabular}


TABLE III: INUNDATION EXTENT IN DIFFERENT LAND COVER CLASSES DUE TO STORM SURGE AND FLOODING IN THE SLR1 SCENARIO (SO. KM)

\begin{tabular}{|c|c|c|c|c|c|c|c|c|c|c|c|c|c|c|c|c|}
\hline Countries & Arable & $\begin{array}{c}\text { Non } \\
\text { Agricultural } \\
\text { Vegetated }\end{array}$ & Forest & $\begin{array}{l}\text { Agricultural } \\
\text { areas }\end{array}$ & Industrial & $\begin{array}{l}\text { Inland } \\
\text { waters }\end{array}$ & $\begin{array}{c}\text { Inland } \\
\text { wetlands }\end{array}$ & $\begin{array}{c}\text { Marine } \\
\text { waters }\end{array}$ & $\begin{array}{l}\text { Maritime } \\
\text { wetlands }\end{array}$ & $\begin{array}{l}\text { Mine } \\
\text { and } \\
\text { dump }\end{array}$ & $\begin{array}{l}\text { Open } \\
\text { spaces }\end{array}$ & Pastures & $\begin{array}{l}\text { Permanent } \\
\text { crops }\end{array}$ & Scrub & Urban & Total \\
\hline Albania & 298.7 & 0.7 & 13.1 & 59.3 & 5.9 & 158.6 & 19.9 & 54.3 & 63.0 & 0.2 & 17.4 & 10.5 & 0.3 & 40.0 & 27.6 & 769.4 \\
\hline Belgium & 292.7 & 2.1 & 2.5 & 167.0 & 13.4 & 27.9 & 1.5 & 28.7 & 2.6 & 4.1 & 0.1 & 103.8 & 0.4 & 3.4 & 6.2 & 656.3 \\
\hline Bosnia and Herzegovina & 1.0 & & 0.0 & 0.5 & & 1.1 & 3.4 & & & & & 0.0 & 0.0 & 0.0 & & 6.1 \\
\hline Bulgaria & 19.4 & 1.7 & 0.0 & 3.0 & 1.0 & 38.9 & 6.1 & 3.4 & 5.4 & 0.2 & 1.6 & 1.8 & 0.1 & 0.4 & 0.2 & 83.2 \\
\hline Croatia & 20.7 & 0.6 & 1.1 & 16.5 & 1.6 & 34.7 & 26.5 & 0.7 & 3.8 & 0.4 & 0.5 & 1.5 & 32.3 & 1.4 & 2.5 & 144.8 \\
\hline Cyprus & 0.2 & 0.4 & 0.0 & 0.1 & 1.8 & & 0.7 & 0.0 & 17.9 & 0.0 & 5.6 & & 0.0 & 2.0 & 0.1 & 28.8 \\
\hline Denmark & 961.7 & 33.4 & 8.9 & 144.8 & 17.1 & 120.8 & 82.1 & 29.6 & 168.6 & 4.2 & 11.9 & 97.0 & 0.7 & 62.3 & 15.7 & 1758.7 \\
\hline Estonia & 0.0 & 0.0 & 0.4 & 1.1 & 0.3 & 11.8 & 11.8 & 10.1 & & 0.1 & 2.1 & 0.2 & & 13.5 & 0.2 & 51.6 \\
\hline Finland & 4.5 & 1.0 & 86.3 & 9.2 & 8.4 & 8.3 & 1.6 & 39.8 & 15.2 & 0.4 & 0.9 & 2.9 & & 4.7 & 4.9 & 188.0 \\
\hline France & 393.7 & 3.9 & 2.5 & 37.0 & 13.0 & 71.6 & 188.5 & 51.9 & 203.8 & 2.9 & 11.7 & 251.2 & 14.2 & 16.0 & 8.2 & 1270.2 \\
\hline Germany & 2429.7 & 21.1 & 45.1 & 17.6 & 54.3 & 212.0 & 255.3 & 71.5 & 162.0 & 5.8 & 9.1 & 4763.9 & 80.5 & 159.5 & 120.6 & 8408.1 \\
\hline Greece & 345.6 & 3.1 & 0.7 & 29.3 & 8.3 & 20.9 & 35.0 & 37.4 & 129.5 & 0.7 & 19.5 & 1.7 & 7.8 & 9.6 & 4.7 & 653.7 \\
\hline Iceland & 0.0 & 0.8 & 0.1 & 0.0 & 1.1 & 20.5 & 7.1 & 55.5 & 13.4 & & 44.5 & 6.4 & & 24.4 & 1.5 & 175.4 \\
\hline Ireland & 16.4 & 1.0 & 3.7 & 6.8 & 1.3 & 23.5 & 7.2 & 10.0 & 9.1 & 0.9 & 1.8 & 37.4 & & 1.1 & 0.7 & 120.9 \\
\hline Italia & 3725.0 & 18.4 & 15.7 & 276.2 & 75.2 & 123.0 & 42.0 & 149.5 & 172.8 & 5.8 & 11.9 & 7.1 & 56.1 & 15.1 & 84.5 & 4778.3 \\
\hline Latvia & 61.0 & 5.4 & 1.9 & 14.4 & 5.4 & 183.0 & 75.9 & 0.1 & & 2.2 & 3.9 & 75.3 & & 7.2 & 3.7 & 439.4 \\
\hline Lithuania & 58.0 & 0.6 & 12.8 & 36.7 & 3.5 & 38.2 & 48.2 & 1.4 & & 0.3 & 3.5 & 152.9 & & 16.0 & 4.7 & 376.7 \\
\hline Montenegro & & 0.5 & 0.6 & 2.2 & 0.2 & 213.7 & 7.5 & 0.5 & 14.6 & & 1.9 & 1.4 & 0.0 & 5.4 & 0.5 & 249.0 \\
\hline Netherlands & 4885.6 & 239.4 & 173.8 & 586.6 & 330.2 & 610.2 & 336.3 & 2.1 & 58.4 & 60.9 & 10.0 & 5342.1 & 37.3 & 155.3 & 820.5 & 13648.8 \\
\hline Norway & 6.9 & 0.4 & 44.5 & 41.6 & 3.8 & 48.8 & 5.2 & 85.0 & 4.2 & 0.2 & 56.9 & 0.4 & & 41.1 & 6.4 & 345.4 \\
\hline Poland & 991.8 & 12.1 & 39.2 & 69.5 & 19.2 & 332.9 & 92.2 & 4.8 & & 8.0 & 6.5 & 618.8 & 1.4 & 19.3 & 48.8 & 2264.5 \\
\hline Portugal & 49.7 & 0.1 & 0.6 & 2.4 & 2.1 & 10.3 & 0.3 & 22.1 & 27.6 & 0.0 & 5.1 & 5.8 & 0.0 & 3.3 & 0.5 & 130.0 \\
\hline Romania & 275.7 & 1.1 & 10.1 & 0.7 & 1.8 & 443.8 & 1098.3 & 520.7 & 54.9 & 1.5 & 21.1 & 5.9 & 0.0 & 72.8 & 3.1 & 2511.4 \\
\hline Slovenia & 0.5 & 0.2 & & 0.6 & 1.3 & 0.7 & & 0.0 & 0.6 & 0.4 & & & 0.2 & 0.0 & 0.0 & 4.6 \\
\hline Spain & 300.0 & 1.5 & 0.7 & 8.8 & 7.5 & 19.4 & 9.5 & 31.2 & 119.3 & 1.6 & 18.2 & 15.8 & 8.2 & 9.0 & 9.7 & 560.5 \\
\hline Sweden & 66.8 & 6.9 & 73.7 & 11.5 & 10.1 & 63.9 & 20.3 & 72.6 & 3.7 & 2.1 & 8.7 & 72.4 & 0.0 & 9.8 & 7.2 & 429.8 \\
\hline Turkey & 37.8 & 2.7 & 2.2 & 19.4 & 4.5 & 281.8 & 39.3 & 34.5 & 81.2 & 2.6 & 37.8 & 5.5 & 3.5 & 8.3 & 4.2 & 565.3 \\
\hline Ukraine & 5.9 & & 0.3 & 0.7 & 0.0 & 1.6 & 13.4 & & 0.0 & & & & & & 0.1 & 22.1 \\
\hline United Kingdom & 872.2 & 8.4 & 2.4 & 4.6 & 21.1 & 41.2 & 73.8 & 19.6 & 39.5 & 4.8 & 1.3 & 221.2 & 0.7 & 10.1 & 7.9 & 1329.0 \\
\hline
\end{tabular}


TABLE IV: INUNDATION EXTENT IN DIFFERENT LAND COVER CLASSES DUE TO STORM SURGE AND FLOODING IN THE SLR2 SCENARIO (SQ. KM)

\begin{tabular}{|c|c|c|c|c|c|c|c|c|c|c|c|c|c|c|c|c|}
\hline Countries & Arable & $\begin{array}{c}\text { Non } \\
\text { Agricultural } \\
\text { Vegetated }\end{array}$ & Forest & $\begin{array}{c}\text { Agricultural } \\
\text { areas }\end{array}$ & Industrial & $\begin{array}{l}\text { Inland } \\
\text { waters }\end{array}$ & $\begin{array}{c}\text { Inland } \\
\text { wetlands }\end{array}$ & $\begin{array}{l}\text { Marine } \\
\text { waters }\end{array}$ & $\begin{array}{l}\text { Maritime } \\
\text { wetlands }\end{array}$ & $\begin{array}{l}\text { Mine and } \\
\text { dump }\end{array}$ & $\begin{array}{c}\text { Open } \\
\text { spaces }\end{array}$ & Pastures & $\begin{array}{l}\text { Permanent } \\
\text { crops }\end{array}$ & Scrub & Urban & Total \\
\hline Albania & 396.4 & 1.1 & 21.3 & 93.9 & 8.5 & 160.0 & 23.0 & 55.5 & 66.6 & 0.4 & 20.7 & 12.3 & 0.6 & 50.7 & 38.8 & 949.6 \\
\hline Belgium & 436.7 & 5.3 & 5.6 & 279.3 & 26.8 & 40.8 & 1.7 & 29.8 & 4.9 & 6.6 & 0.4 & 152.2 & 0.5 & 6.2 & 23.6 & 1020.4 \\
\hline Bosnia and Herzegovina & 3.7 & & 0.1 & 1.7 & & 11.2 & 11.9 & & & 0.0 & & 0.0 & 0.5 & 0.2 & 0.0 & 29.4 \\
\hline Bulgaria & 28.9 & 3.3 & 0.2 & 6.0 & 2.6 & 42.1 & 10.4 & 3.8 & 7.6 & 0.3 & 3.2 & 3.6 & 0.2 & 1.2 & 0.5 & 113.7 \\
\hline Croatia & 23.8 & 1.4 & 2.6 & 23.2 & 3.5 & 35.8 & 31.5 & 2.0 & 4.7 & 0.4 & 1.0 & 3.7 & 44.6 & 4.1 & 7.6 & 189.9 \\
\hline Cyprus & 0.9 & 1.0 & 0.0 & 0.3 & 3.6 & 0.0 & 1.8 & 0.5 & 18.9 & 0.0 & 10.1 & 0.0 & 0.1 & 3.3 & 0.4 & 41.2 \\
\hline Denmark & 1463.8 & 64.2 & 16.4 & 226.6 & 35.0 & 135.0 & 117.4 & 34.8 & 229.6 & 5.4 & 22.0 & 145.0 & 1.5 & 93.5 & 44.2 & 2634.3 \\
\hline Estonia & 0.2 & 0.1 & 1.9 & 4.7 & 0.9 & 18.9 & 44.4 & 28.2 & 0.9 & 0.1 & 6.9 & 1.1 & & 41.6 & 0.7 & 150.5 \\
\hline Finland & 59.3 & 6.3 & 601.2 & 63.8 & 35.0 & 32.5 & 4.8 & 60.3 & 28.1 & 2.2 & 2.8 & 14.8 & & 31.0 & 40.0 & 982.1 \\
\hline France & 865.0 & 12.2 & 8.4 & 121.0 & 36.1 & 160.1 & 295.6 & 88.8 & 419.9 & 4.2 & 28.7 & 706.5 & 43.9 & 39.0 & 31.6 & 2861.0 \\
\hline Germany & 2815.1 & 33.3 & 76.3 & 19.5 & 88.1 & 229.2 & 280.5 & 74.1 & 192.0 & 7.7 & 12.6 & 5456.2 & 112.1 & 198.3 & 235.6 & 9830.7 \\
\hline Greece & 580.6 & 8.1 & 2.0 & 71.8 & 17.6 & 33.2 & 50.8 & 49.6 & 195.4 & 0.8 & 30.1 & 2.9 & 18.6 & 15.5 & 14.0 & 1091.0 \\
\hline Iceland & 0.0 & 1.7 & 0.4 & 0.0 & 2.7 & 58.3 & 20.4 & 63.8 & 17.5 & 0.0 & 94.5 & 16.9 & & 64.7 & 3.1 & 344.0 \\
\hline Ireland & 22.0 & 3.5 & 7.3 & 17.3 & 4.4 & 42.3 & 24.1 & 17.9 & 28.5 & 1.1 & 5.2 & 118.7 & & 4.1 & 3.0 & 299.3 \\
\hline Italia & 4417.6 & 28.0 & 29.8 & 433.5 & 121.6 & 132.7 & 50.6 & 167.8 & 209.6 & 7.3 & 30.6 & 15.6 & 81.9 & 27.9 & 162.7 & 5917.2 \\
\hline Latvia & 96.4 & 9.1 & 5.9 & 35.4 & 12.0 & 191.7 & 91.4 & 0.3 & & 3.2 & 8.3 & 103.4 & & 16.3 & 8.6 & 581.9 \\
\hline Lithuania & 71.6 & 1.1 & 20.8 & 47.7 & 6.0 & 39.5 & 55.9 & 1.4 & & 0.5 & 6.2 & 170.6 & 0.0 & 20.0 & 7.8 & 449.0 \\
\hline Montenegro & & 0.9 & 1.3 & 5.7 & 0.4 & 214.3 & 9.9 & 0.5 & 15.0 & & 2.1 & 3.0 & 0.1 & 7.4 & 1.1 & 261.7 \\
\hline Netherlands & 5295.0 & 295.7 & 221.3 & 712.2 & 422.3 & 646.1 & 366.1 & 3.2 & 72.6 & 68.8 & 16.9 & 5873.1 & 41.1 & 191.1 & 1117.8 & 15343.2 \\
\hline Norway & 38.0 & 2.5 & 123.2 & 190.7 & 12.4 & 70.0 & 27.6 & 183.2 & 10.3 & 0.4 & 235.3 & 1.7 & & 176.0 & 25.8 & 1097.1 \\
\hline Poland & 1158.2 & 17.2 & 66.2 & 82.1 & 29.3 & 335.6 & 99.8 & 6.6 & & 9.0 & 12.5 & 742.4 & 1.5 & 27.2 & 72.9 & 2660.6 \\
\hline Portugal & 145.5 & 0.6 & 1.2 & 7.4 & 4.8 & 16.7 & 1.3 & 31.0 & 66.1 & 0.2 & 11.0 & 13.3 & 0.2 & 8.8 & 1.8 & 309.7 \\
\hline Romania & 469.0 & 2.6 & 28.1 & 2.4 & 5.2 & 482.2 & 1717.6 & 521.6 & 61.4 & 2.0 & 43.4 & 14.1 & 0.0 & 136.7 & 8.3 & 3494.7 \\
\hline Slovenia & 1.0 & 0.3 & 0.0 & 1.1 & 2.5 & 0.7 & & 0.0 & 0.6 & 0.4 & & & 0.5 & 0.0 & 0.1 & 7.3 \\
\hline Spain & 538.5 & 4.5 & 3.2 & 24.8 & 20.8 & 36.6 & 14.2 & 41.1 & 285.0 & 3.1 & 29.2 & 35.6 & 27.3 & 16.7 & 24.8 & 1105.4 \\
\hline Sweden & 162.5 & 15.4 & 304.7 & 26.2 & 32.3 & 123.4 & 36.9 & 129.4 & 8.0 & 2.3 & 30.6 & 134.4 & 0.1 & 28.5 & 30.0 & 1064.6 \\
\hline Turkey & 143.7 & 8.3 & 9.6 & 68.3 & 12.3 & 296.5 & 76.5 & 43.6 & 145.4 & 3.0 & 78.1 & 17.5 & 11.7 & 18.1 & 13.0 & 945.7 \\
\hline Ukraine & 11.7 & & 1.0 & 2.5 & 0.2 & 4.0 & 22.8 & & 0.2 & & & & & & 0.5 & 42.9 \\
\hline United Kingdom & 1798.9 & 23.7 & 7.3 & 7.6 & 48.9 & 69.6 & 153.1 & 46.7 & 100.7 & 8.4 & 5.7 & 377.7 & 4.0 & 30.5 & 27.8 & 2710.6 \\
\hline
\end{tabular}


Although the areas under urban fabric affected by SLR scenarios is small compared to other land use classes, it is important to note that the urban fabric has higher infrastructure and population density than other land cover classes. Table II, Table III, and Table 4 show the list of countries and the areas estimated to be affected by SLR for the other 15 land use land cover classes. Because the Netherlands is a low-lying country, the urban fabric area affected by SLR scenarios will be higher than that of other countries (Fig. 2b).

A large area of urban fabric will be affected in the Netherlands, Germany, Italy, and Poland (Fig. 2b). Denmark, Finland, Albania, France, Sweden, and the UK are also estimated to be affected significantly by the SLR scenarios (Fig. 2a).
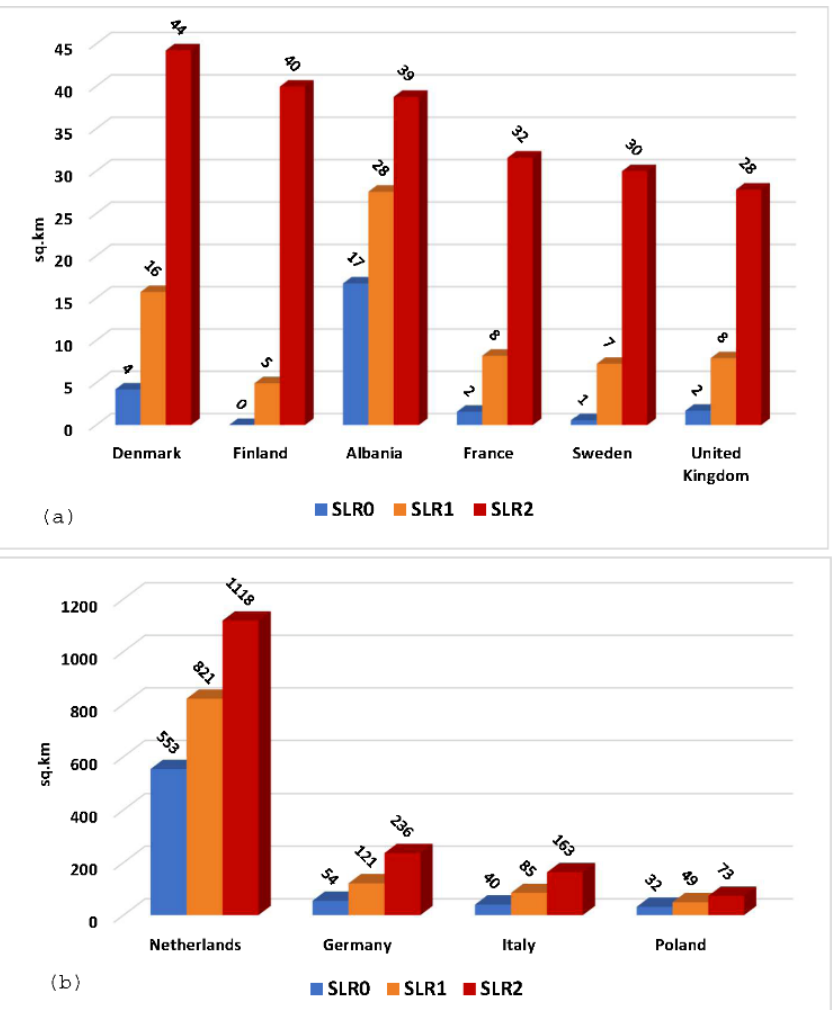

Fig. 2. (a \& b) Urban fabric area affected by the three SLR scenarios at year 2100.

Although areas in industrial, commercial, and transportation units that are estimated to be affected by the SLR scenarios are lower compared to other categories, it is important to note that these areas have significant infrastructural investment, and any damage due to SLR and related causes, such as flooding and water logging, could cost the countries in both the short term and long term.

Inundation in land cover classes, such as arable lands, pastures, wetlands, and forests, will not only incite economic losses but also bring significant changes in local ecosystems in the long run.

Another major impact of SLR in Europe is the seawater intrusion in coastal aquifers. Seawater intrusion occurs when seawater enters into groundwater in coastal aquifers. This will deteriorate the groundwater quality by increasing salinity levels to above drinking and irrigation standards for water [54] Salinity problems in many European coastal aquifers is very common.

Saltwater intrusion is common in the coastal aquifer along the southern Adriatic Coast of the Po Plain in Italy, the Netherlands, Spain, and Portugal. Seawater intrusion has been documented within many coastal aquifers in Europe, particularly along the North Sea [55], [56] and the Mediterranean Sea [57]. Our results indicate that large areas of inland water bodies and inland wetlands will be affected by SLR in Europe. SLR scenarios will affect inland waters and inland wetlands (Tables II, III and IV). Most of the countries studied will face water quality issues due to SLR and its impact on inland water bodies and inland wetlands. The Netherlands, Romania, Poland, Turkey, Germany, Montenegro, Latvia, France, Albania, Denmark, Italy, Sweden, and the UK will have significant SLR impacts on water quality in wetlands and inland waters.

\section{DISCUSSION AND CONCLUSION}

Changes in global mean sea level (GMSL) result from thermal expansion of the oceans that occurs as a result of warming ocean water, melting glaciers and small ice caps, and the disintegration of the large Greenland and Antarctic Ice Sheets. The IPCC AR5 predicted a likely rise in GMSL in various representative concentration pathway (RCP) trajectories. For RCP8.5, the rise in GMSL by 2100 is projected to be in the range of $0.53-0.97 \mathrm{~m}$. An Antarctic Ice Sheet collapse of more than the predicted amount could cause GMSL to rise substantially above the predicted range [58]. Studies have also suggested that an upper limit of the SLR due to the contributions from the Greenland and Antarctic Ice Sheets during the 21 st century is $1.8 \mathrm{~m}[59,60]$. Studies have also used 1.5-2.5 m MSL as upper estimates during the $21 \mathrm{st}$ century [61].

Despite various upper limits suggested by diverse models and studies, it is imperative to study the estimate of the longterm impacts of SLR on coastal ecosystems and formulate risk management strategies. Regional and local sea levels differ from the global mean owing to large-scale factors such as nonuniform changes in ocean density and changes in ocean circulation. They also differ due to local and regional factors such as vertical land movement [18].

Relative sea level change along most of the European coastline is similar to the global average with some exceptions in the northern Baltic Sea and northern Atlantic Coast where sea level is rising slower than elsewhere [24]. In European coastal zones, SLR will bring flooding, coastal erosion, and the submergence of lands along continental coastlines and on islands [18]. Saltwater intrusion into low-lying aquifers is another potential SLR impact, thus threatening water supplies and endangering coastal ecosystems and wetlands. Increased flooding intensity will also raise the risk to human settlements, properties, and infrastructure. Industries, such as tourism, transportation, and recreation, will be severely affected. SLR brings extreme events such as storm surges. Of most concern are events when the surge coincides with high tidal levels 
when extreme water levels increase the risk of coastal flooding. The European coastline will see both an increase and decrease of average wave height, depending on the location and season [18].

This study used an inundation model to estimate the extent of land that will be impacted due to extreme events brought by three SLR scenarios at 2100: SLR0 - the base sea level; SLR1 - $1 \mathrm{~m}$ SLR; and SLR2 - $2 \mathrm{~m}$ SLR. The EU-DEM v1.1 digital elevation model, land cover data from CLC2018, and monthly averaged SLA files from 2013 to 2015 were used in the model. In the SLR0 scenario about 8.7 million people are estimated to be affected at 2100 because they will be living in coastal LAUs. Similarly, an estimated 11.6 million people in the SLR1 scenario will be affected at 2100 and an estimated 14.8 million people in the SLR2 scenarios in the European coastlines will be affected at 2100 .

The coastal ecosystem and infrastructure will also be in dire danger due to SLR. Arable lands and pastures are the two top land cover classes that will be affected by SLR. However, land under urban fabric and transportation are also two important land cover types affected by SLR, which can induce major economic costs to coastal countries. Water quality will be another issue that must be addressed because of SLR. Significant areas of underwater bodies and wetlands will come in contact with sea water due to the extreme events caused by SLR.

This study results are in agreement with many other studies in Europe. It is clear that increase in extreme sea level along the European coast will be the result of changes in mean sea level and changes in wave and storm surge [18]. The high sea level and heavy precipitation will result in large runoff and may cause compound flooding in low-lying coastal [62]. A study [63] has estimated the average annual losses from coastal flooding in the 17 main coastal cities in EEA member countries could be EUR 31 billion in 2100 under the RCP8.5 scenario. Other studies have estimated the number of people exposed 1.52-3.65 million by the end of the century [18], [64].

However, there are some limitation in this study. This study uses extreme cases of SLR scenarios ( $1 \mathrm{~m}$ and $2 \mathrm{~m}$ ) for the entire European coastline which are very high compared to the most projections of SLR in European coast. There are also local variations in SLR within the European coast. However, studies have suggested the global mean sea level reach $1.5 \mathrm{~m}$ to $2.5 \mathrm{~m}$ by $21^{\text {st }}$ century [22], [23]. For the lack of data, this study uses a simple population growth projection, however, a population estimation inclusive of future socio-economic economic growth scenarios inn coastal Europe would be more appropriate.

European countries have taken several steps to mitigate the impacts of SLR. Concrete planning for SLR above the base levels is needed for many areas of European coastlines. Upgradation of coastal infrastructure and plans for future management of coastal ecosystems are needed. There are ecosystem management strategies already in place in some European countries, including for saltmarshes and sand dunes. A balanced approach is needed to protect the economic, sociological, and biological interests and options along European coastlines.

\section{REFERENCES}

[1] IPCC. Special Report on the Ocean and Cryosphere in a Changing Climate. 2019. [H.O. Pörtner, D.C. Roberts, V. Masson-Delmotte, P. Zhai, M. Tignor, E. Poloczanska, K. Mintenbeck, M. Nicolai, A. Okem, J. Petzold, B. Rama, N. Weyer (eds.)]. Cambridge University Press, Cambridge, United Kingdom and New York, NY, USA, In press.

[2] X. Chen, X. Zhang, X. Church, and al, "The increasing rate of global mean sea-level rise during 1993-2014," Nature Clim Change, vol. 7, pp. 492-495, 2017, doi: 10.1038/nclimate3325.

[3] H. B. Dieng, A. Cazenave, B. Meyssignac, and M. Ablain, "New estimate of the current rate of sea level rise from a sea level budget approach," Geophys. Res. Lett, vol. 44, pp. 3744-3751, 2017, doi: 10.1002/2017GL073308.

[4] T. R. Anderson, "Modeling multiple sea level rise stresses reveals up to twice the land at risk compared to strictly passive flooding methods," Sci Rep, vol. 4484, p. 8, 2018, doi: 10.1038/s41598-018-32658-x.

[5] S. Rahmstorf, "A Semi-Empirical Approach to Projecting Future SeaLevel Rise," Science, vol. 315, no. 5810, pp. 368-370, 2007, doi: 10.1126/science. 1135456 .

[6] W. T. Pfeffer, J. T. Harper, and S. O'Neel, "Kinematic Constraints on Glacier Contributions to 21st-Century Sea-Level Rise," Science, vol. 321, no. 5894, pp. 1340-1343, 2008, doi: 10.1126/science.1159099.

[7] D. B. Bahr, M. Dyurgerov, and M. F. Meier, "Sea-level rise from glaciers and ice caps: A lower bound," Geophys Res Lett, vol. 36, p. 03501, 2009, doi: 10.1029/2008GL036309.

[8] Grinsted, J. C. Moore, and S. Jevrejeva, "Reconstructing sea level from paleo and projected temperatures 200 to 2100AD," Clim. Dyn, vol. 34, pp. 461-72, 2010.

[9] J. T. Overpeck, B. L. Otto-Bliesner, G. H. Miller, D. R. Muhs, R. B. Alley, and J. T. Kiehl, "Paleoclimatic Evidence for Future Ice-Sheet Instability and Rapid Sea-Level Rise," Science, vol. 311, no. 5768, p. 1747, Mar. 2006, doi: 10.1126/science.1115159.

[10] J. E. Hansen, Scientific reticence and sea level rise, vol. 2, no. 2. Environ Res Lett, 2007.

[11] E. McLeod, "Sea-level rise impact models and environmental conservation: A review of models and their applications," Ocean and Coastal Management, vol. 53, pp. 507-517, 2010, doi: 10.1016/j.ocecoaman.2010.06.009.

[12] R. McLeman, "Migration and displacement risks due to mean sea-level rise," Bulletin of the Atomic Scientists, vol. 74, no. 3, pp. 148-154, 2018, doi: 10.1080/00963402.2018.1461951.

[13] W. Kron, "Coasts: the high-risk areas of the world," Nat Hazards, vol. 66, pp. 1363-1382, 2013, doi: 10.1007/s11069-012-0215-4.

[14] D. Lincke and J. Hinkel, "Economically robust protection against 21st century sea-level rise," Global environmental change, vol. 51, pp. 6773, 2018, doi: 10.1016/j.gloenvcha.2018.05.003.

[15] B. Neumann, "Future Coastal Population Growth and Exposure to SeaLevel Rise and Coastal Flooding - A Global Assessment," PLoS ONE, vol. 10, no. 3, p. 0118571, 2015, doi: 10.1371/journal.pone.0118571.

[16] K. J. E. Walsh, "Tropical cyclones and climate change," WIREs Clim Change, vol. 7, pp. 65-89, 2016, doi: 10.1002/wcc.371.

[17] M. E. Hauer, J. M. Evans, and D. R. Mishra, "Millions projected to be at risk from sea-level rise in the continental United States," Nature Clim. Change, vol. 6, no. 7, pp. 691-695, 2016, doi: 10.1038/nclimate2961.

[18] E.E.A., Climate Change adaptation, water and marine environment: Global and European sea-level rise. 2019.

[19] G. Hugo, "Future demographic change and its interactions with migration and climate change," Global Environmental Change, vol. 21, no. 1, pp. 21-33, 2011, doi: 10.1016/j.gloenvcha.2011.09.008.

[20] K. J. Curtis and S. A, "Understanding the demographic implications of climate change: estimates of localized population predictions under future scenarios of sea-level rise," Population \& Environment, vol. 33, pp. 28-54, 2011.

[21] T. Haer, "Relative sea-level rise and the conterminous United States: Consequences of potential land inundation in terms of population at risk and GDP loss," Global Environmental Change, vol. 23, no. 6, pp. 1627-1636, 2013, doi: 10.1016/j.gloenvcha.2013.09.005. 
[22] C. Katsman, "Exploring high-end scenarios for local sea level rise to develop flood protection strategies for a low-lying delta-the Netherlands as an example," Clim. Change, vol. 109, pp. 617-64, 2011.

[23] R. Sriver, N. Urban, R. Olson, and K. Keller, "Toward a physically plausible upper bound of sea-level rise projections," Clim. Change, vol. 115, pp. 893-902, 2012.

[24] J. A. Church et al., Sea Level Change. In: Climate Change 2013: The Physical Science Basis. Contribution of Working Group I to the Fifth Assessment Report of the Intergovernmental Panel on Climate Change. Cambridge, United Kingdom and New York, NY, USA: Cambridge University Press, 2013.

[25] Hinkel J., et al. Coastal flood damage and adaptation costs under 21st century sea-level rise, Proc.Natl.Acad.Sci, vol. 111, no. 9. 2014.

[26] M. Lichter and D. Felsenstein, "Assessing the costs of sea-level rise and extreme flooding at the local level: a GIS-based approach," Ocean \& Coastal Management, vol. 59, pp. 47-62, 2012, doi: 10.1016/j.ocecoaman.2011.12.020.

[27] J. Song, "Developing a theoretical framework for integrated vulnerability of businesses to sea level rise," Nat Hazards, vol. 84, pp. 1219-1239, 2016, doi: 10.1007/s11069-016-2483-x.

[28] J. Woodruff, J. Irish, and S. Camargo, "Coastal flooding by tropical cyclones and sea-level rise," Nature, vol. 504, pp. 44-52, 2013, doi: 10.1038 /nature 12855 .

[29] X. Fu, "Living on the edge: Estimating the economic cost of sea level rise on coastal real estate in the Tampa Bay region, Florida," Ocean \& Coastal Management, vol. 133, pp. 11-17, 2016.

[30] T. G. Frazier, "Influence of potential sea level rise on societal vulnerability to hurricane storm-surge hazards, Sarasota County, Florida," Applied Geography, vol. 30, no. 4, pp. 490-505, 2010.

[31] S. Hallegatte, "Assessing climate change impacts, sea level rise and storm surge risk in port cities: a case study on Copenhagen," Climatic Change, vol. 104, pp. 113-137, 2011, doi: 10.1007/s10584-010-99783.

[32] C. C. Shepard, Assessing future risk: quantifying the effects of sea level rise on storm surge risk for the southern shores of Long Island, vol. 60. New York: Nat Hazards, 2012.

[33] C. Tebaldi, B. H. Strauss, and Z. C. E, "Modelling sea level rise impacts on storm surges along US coasts," Environmental Research Letters, vol. 7, no. 1, p. 014032, 2012.

[34] G. W. Yohe and M. E. Schlesinger, "Sea-Level Change: The Expected Economic Cost of Protection Or Abandonment in the United States," Climatic Change, vol. 38, pp. 447-472, 1998, doi: 10.1023/A:1005338413531.

[35] D. Anthoff, R. J. Nicholls, and R.S.J. Tol, "The economic impact of substantial sea-level rise," Mitig Adapt Strateg Glob Change, vol. 15. 2010.

[36] J. P. Ericson, "Effective sea-level rise and deltas: Causes of change and human dimension implications," Global and Planetary Change, vol. 50, no. 1-2, pp. 63-82, 2006.

[37] S. Wu, B. Yarnal, and A. Fisher, "Vulnerability of coastal communities to sea-level rise: a case study of Cape May County," vol. 22. Climate Research, 22(3), 255-270. 2002.

[38] L. R. Kleinosky, B. Yarnal, and A. Fisher, "Vulnerability of Hampton Roads, Virginia to Storm-Surge Flooding and Sea-Level Rise," Nat Hazards, vol. 40, pp. 43-70, 2007, doi: 10.1007/s11069-006-0004-z.

[39] T. Spencer, "Global coastal wetland change under sea-level rise and related stresses: the DIVA Wetland Change Model," Global Planet. Change, vol. 139, pp. 15-30, 2016, doi: 10.1016/j.gloplacha.2015.12.018.

[40] R. J. Nicholls, F. Hoozemans, and M. Marchand, "Increasing flood risk and wetland losses due to global sea-level rise: regional and global analyses," Glob. Environ. Change, vol. 9, pp. 69-87, 1999, doi: 10.1016/S0959-3780(99)00019-9.

[41] F. M. J. Hoozemans and C. H. Hulsbergen, Sea-level rise: a world-wide assessment of risk and protection costs. Climate Change: Impact on Coastal Habitation.1995. Lewis Publishers.

[42] F. M. J. Hoozemans, M. Marchand, and H. A. Pennekamp, A Global Vulnerability Analysis: Vulnerability Assessment for Population, Coastal Wetlands and Rice Production on a Global Scale, 2nd ed. Delft Hydraulics, the Netherlands, 1993.

[43] IPCC, Global climate change and the rising challenge of the sea. Report of the Coastal Zone Management Subgroup. Rijkswaterstaat: IPCC Response Strategies Working Group, 1992.
[44] R. J. Nicholls, "Analysis of global impacts of sea-level rise: a case study of flooding Phys," Chem. Earth, vol. 27, 32, pp. 1455-1466, 10 1016 1474-7065 02 00090-6, 2002.

[45] H. Alistair, "Assessing the characteristics and drivers of compound flooding events around the UK coast," Hydrology and Earth System Sciences, vol. 23, pp. 3117-3139, 2019, doi: 10.5194/hess-23-31172019).

[46] M. Ablain, J. F. Legeais, and P. Prandi, "Satellite Altimetry-Based Sea Level at Global and Regional Scales," Surv Geophys, vol. 38, pp. 7-31, 2017, doi: 10.1007/s10712-016-9389-8.

[47] E.E.A., European Digital Elevation Model (EU-DEM), version 1.1. 2020.

[48] M. VanKoningsveld, "Living with sea-level rise and climate change: a case study of the Netherlands," Journal of coastal research, vol. 24, no. 2, pp. 367-379, 2008, doi: 10.2112/07A-0010.1.

[49] S. Santamaria-Aguilar, A. Arns, and A. T. Vafeidis, "Sea-level rise impacts on the temporal and spatial variability of extreme water levels: A case study for St Peter-Ording," Germany, J. Geophys. Res. Oceans, p. 122,2742-2759, 2017, doi: 10.1002/2016JC012579.

[50] J. Fenger, "Danish Attitudes and Reactions to the Threat of Sea-Level Rise," Journal of Coastal Research, vol. 24, no. 2, pp. 394-402, 2008.

[51] M. Bondesan, V. Favero, and M. J. Vinals, "New evidence on the evolution of the Po-delta coastal plain during the Holocene," Quat. Int, pp. 29-30, 105-110, 1995, doi: 10.1016/1040-6182(95)00012-8.

[52] C. Da Lio and L. Tosi, "Vulnerability to relative sea-level rise in the Po river delta (Italy," Estuarine, Coastal and Shelf Science, vol. 228, p. 106379, 2019.

[53] D. Paprotny and P. Terefenko, "New estimates of potential impacts of sea level rise and coastal floods in Poland," Nat Hazards, vol. 85, pp. 1249-1277, 2017, doi: 10.1007/s11069-016-2619-z.

[54] Lotfata and S. Ambinakudige, "Degradation of groundwater quality in the coastal aquifers of the USA," Sustainable Water Resources Management, vol. 6, no. 41, 2020, doi: 10.1007/s40899-020-00403-w.

[55] G. P. H. O. Essink, "Saltwater intrusion in 3D large scale aquifers a Dutch case," Phys. Chem. Earth, vol. 26, pp. 337-344, 2001.

[56] Vandenbohede, K. Walraevens, and W. De Breuck, "What does the interface on the fresh-saltwater distribution map of the Belgian coastal plain represent?," GEOLOGICA BELGICA, vol. 18, no. 1, pp. 31-36, 2015.

[57] F. J. Alcala and E. Custodio, "Using the $\mathrm{Cl} / \mathrm{Br}$ ratio as a tracer to identify the origin of salinity in aquifers in Spain and Portugal," $J$. Hydrol, vol. 359, pp. 189-207, 2008.

[58] Vousdoukas M.I. Mentaschi, E. Voukouvalas, M. Verlaan, and L. Feyen, "Extreme Sea Levels on the Rise along Europe's Coasts," Earth's Future, 5 (3), 304-23. 2017. https://doi.org/10.1002/2016EF000505.

[59] Brown, et. al. "The Impacts and Economic Costs of Sea-Level Rise in Europe and the Costs and Benefits of Adaptation," in Summary of Results from the EC RTD Climate Cost Project, The Climate Cost Project, Technical Policy Briefing Note 2, Stockholm: Stockholm Environment Institute, 2011.

[60] M.J.C. Ciscar, et al., Climate Impacts in Europe: The JRC PESETA II Project, JRC Scientific and Policy Reports (Seville: European Commission - Joint Research Centre Institute for Prospective Technological Studies, Institute for Environment and Sustainability, 2014, [Online]. Available: http://ipts.jrc.ec.europa.eu/publications/pub.cfm?id=7181.

[61] L. M. Abadie, "Climate Risk Assessment under Uncertainty: An Application to Main European Coastal Cities," Front. Mar. Sci, vol. 3, pp. 1-13, 2016, doi: 10.3389/fmars.2016.00265.

[62] E. Bevacqua et al., 'Higher Probability of Compound Flooding from Precipitation and Storm Surge in Europe under Anthropogenic Climate Change,' Science Advances 5, no. 9 (September 2019): eaaw5531, https://doi.org/10.1126/sciadv.aaw5531.

[63] Luis M. Abadie, Elisa Sainz de Murieta, and Ibon Galarraga, 'Climate Risk Assessment under Uncertainty: An Application to Main European Coastal Cities,' Frontiers in Marine Science 3 (16 December 2016), https://doi.org/10.3389/fmars.2016.00265.

[64] Michalis I. Vousdoukas et al., 'Climatic and Socioeconomic Controls of Future Coastal Flood Risk in Europe', Nature Climate Change 8, no. 9 (September 2018): 776-80, https://doi.org/10.1038/s41558-018-0260. 